DOI : 10.33451/florafauna.v26i1pp93-95

FLORA AND FAUNA

ISSN 2456 - 9364 (Online)

2020 Vol. 26 No. 1 PP 93-95

ISSN 0971 - 6920 (Print)

\title{
Herbaceous flora from Daund Tehsil of Pune District (M.S.), India
}

J.G. Bagal

Department of Botany,

E. S. Divekar College, VARVAND,

Tal. DAUND, Dist. PUNE -412215. (M.S.), INDIA.

E-mail: bagaljg@gmail.com

Received : 15.03.2020; Revised : 18.04.2020; Accepted : 27.04.2020

\begin{abstract}
The regional floristic studies are very important and it can be achieved by exploration of smaller areas. This is useful in the revision of existing flora. In present paper an account of herbaceous flora from Daund Tahsil of Pune District of Maharashtra state excluding trees and aquatics are highlighted. This region experiences semi-arid climate. Plant exploration was conducted to determine herbaceous plant species in Daund Tahsil. Herbaceous flora includes 348 species of Angiosperms. Out of 348 species, 241 species are belonging to Dicotyledons while 107 species are of Monocotyledons. The status of species, population and ecological diversity form the baseline information. The family Poaceae (48 Species), Asteraceae (43 Species) and Fabaceae (37 Species) are dominant families of herbaceous flora in Daund Tahsil.
\end{abstract}

$\begin{array}{lll}\text { Figure : } 00 & \text { References : } 28 & \text { Tables : } 02\end{array}$

KEY WORDS : Daund, Herbaceous flora, Pune.

\section{Introduction}

Herbs are major components of plant diversity and are an important segment of global biodiversity. India is having richest biodiversity in the world. The Flora of India is consisted of 47513 plant species of all groups and 18117 flowering plant species ${ }^{2}$. India is also known as a mega-diversity center among 12 in the world. Vegetation may be described as the plant life of a region. Environmental condition supports the diversity of different plant species. The current study focuses on documentation of diversity of herbaceous Plants in Daund Tahsil of Pune Disrtict (Maharashtra), India.

Biodiversity is the capital asset of a nation and form the foundation upon which the human civilization are built. Biodiversity offers several direct and indirect economic benefits to human kind. Among different groups of plants, flowering plants play an important role and will continue to play major role in shaping the word's civilization $^{27}$. Cultural, economic and overall development of a particular region largely depend on the careful exploration, utilization as well as conservation of its natural resources. Therefore assessment and documentation of biodiversity have become a urgent need of the day. There is an urgent need of repeated floristic studies to access biodiversity to know the changes in the floristic composition of region in time and space.

Daund Tahsil in Pune district is situated on the margins of Bhima River. Daund Tahsil consists of 102 villages and one urban centre. Geographically this region extends from $18^{0} 18^{\prime}$ to $18^{0} 41^{\prime}$ North Latitude and $74^{\circ} 07^{\prime}$ to $74^{0} 51^{\prime}$ East Longitude (Fig. 1). The geographical area

TABLE-1 : Plant Groups.

\begin{tabular}{l|c|c|c}
\hline Plant Group & Families & Genera & Species \\
\hline I) Dicotyledons & 51 & 174 & 241 \\
\hline A) Polypetalae & 26 & 69 & 104 \\
\hline B) Gamopetalae & 15 & 79 & 100 \\
\hline C) Monochlamydae & 10 & 26 & 37 \\
\hline II) Monoctyledons & 22 & 80 & 107 \\
\hline$\quad$ Total & 73 & 254 & 348 \\
\hline
\end{tabular}


of the study region is $1289.86 \mathrm{Sq} . \mathrm{Km}$. (128986 hector) according to 2011 census. The average height of study area is 554 meters from mean sea level. The river Bhima and its tributary rivers Mula-Mutha are dominating drainage pattern in study region. Agriculture is predominant in Daund Tahsil and it provides livelihood to $66.93 \%$ population.

The earlier studies, on the herbaceous flora of the different regions of the country have been made by different workers $3,5,12,14,15,17,19,25$.

\section{Material and Methods}

The exploration of the area under study includes the planned study tours to various places for herbaceous plant species collection. It was carried out during 2015 2018. Several daily and seasonal field tours were made to cover the entire Daund Tahsil. Flowering and fruiting specimens were collected and field observations on habit, habitat, color of flower, local name, and relative abundance, associated plants, economic and medicinal uses etc. were noted. Close up of flowering / fruiting material and habit alongwith associated plants were photographed. Special attention was paid to collect the plants from different areas and as far as possible all localities have been covered during all seasons.

The laboratory work was mainly in the form of the correct identification of collected specimens. The specimens were identified with the help of published flora like Flora of India ${ }^{8}$, Flora of presidency of Bombay ${ }^{6}$, The Flora of the Maharashtra state ${ }^{24,26}$. Flora of Kolhapur District ${ }^{27}$, 'Flora of Baramati' ${ }^{4}$. Author citation and nomenclature of each plant species was verified with International Plant Name Index (IPNI, 2015), Catalogue of life (2016) and The Plant list (2013).

Names of the plants specimens were searched concerning with the different herbaria especially : Herbarium of Botanical survey of India (B.S.I.), Western circle, Pune, Department of Botany, Savitribai Phule Pune University, Pune, Agharkar Herbarium of Maharashtra Association (AHMA), Agharkar Research Institute (A.R.I.) Pune.
TABLE- 2 : Ten Dominant Families of Herbaceous Flora of Daund Tahsil

\begin{tabular}{l|l|c}
\hline $\begin{array}{l}\text { Sr. } \\
\text { No. }\end{array}$ & Family & No. of Species \\
\hline 1 & Poaceae & 48 \\
\hline 2 & Asteraceae & 43 \\
\hline 3 & Fabaceae & 37 \\
\hline 4 & Amaranthaceae & 13 \\
\hline 5 & Cyperaceae & 13 \\
\hline 6 & Lamiaceae & 11 \\
\hline 7 & Euphorbiaceae & 10 \\
\hline 8 & Malvaceae & 09 \\
\hline 9 & Solanaceae & 09 \\
\hline 10 & Liliaceae & 08 \\
\hline
\end{tabular}

\section{Results and Discussion}

The work embodied in this communication is the result of three years collection of herbaceous plants from different localities in Daund Tahsil. The present investigation revealed that total herbaceous flora includes 348 species, 254 genera belonging to 73 families of Angiosperms. Out of 348 species, 241 species, 174 genera and 51 families are belonging to Dicotyledons while 107 species, 80 genera and 22 families are of Monocotyledons. (Table -1). The family Poaceae (48 Species), Asteraceae (43 Species) and Fabaceae (37 Species) are dominant families of herbaceous flora in Daund Tahsil (Table-2).

\section{References}

1. Aher SK. Floristic diversity assessment of Parner Tahsil, Maharashtra (India). Indian J. Applied \& Pure Bio. 2015; 30 (2):123-130.

2. Arisdason W, Lakshminarasimhan P. Status plant diversity in India: An overview. Central national herbarium, Botanical Survey of India, Howrah. Retrieved from http://www.bsienvis.nic.in/Database/Status of plant Diversity in India 17566.aspx. 2015-2016.

3. Bagal JG, Deokule SS, Ghalme RL. Assessment of Floristic Diversity of Daund Tehsil from Pune District (Maharastra). Bionano frantier, Mumbai. 2012; 5(1) : 63-65 
4. Behera SK, Misra MK. Floristic and structure of the herbaceous vegetation of four recovering forest stands in the Eastern Ghats of India. Biodiversity and Conservation. 2004; 15 : 2263-2285.

5. Bhagat RB, Shimple VB, Deshmukh RB. Flora of Baramati. Published by Bhagat RB, Hol (8-Phata), Baramati, Pune. 2008.

6. Buba T. Impact of different types of land use on pattern of herbaceous plant community in the Nigerian Northern Guinea Savanna. Journal of Agriculture and Ecology Research International. 2015; 4(4):151-165.

7. Cooke T. The Flora of the Presidency of Bombay London. 2 vols. (Repr. edition), B. S. I. Calcutta. (1901- 1908), 1958.

8. Diane B, Leonard F. The herbarium handbook (ed.) Royal botanical gardans, Kew, UK. 1998.

9. Hooker JD. Flora of British India. Vol. I-VII. Reeve and Co. Ltd.London. 1872-1897.

10. Jain SK, Rao RR; A Handbook of Field and Herbarium Methods. Today and Tomorrow's Pub., New Delhi, 1978. 2. Babu CR; Herbaceous Flora of Dehradun, CSIR Publication, New Delhi. 1977.

11. Kharat TD, Mokat DN. Floristic and Ecological studies of Mayureshwar and Rehekuri wildlife sanctuaries, International Journal of Botany Studies. 2018; 3 (2) : 29-37.

12. Kulkarni AV, Mahajan DM, Bhore A, Ghotkule K, Waghmare. Tree species assessment at Lohgad and Visapur fort - A Part of Western Ghats, Maharashtra (India). Indian Forester. 2015; 141(5):549-553.

13. Lekhak MM, Yadav SR. Herbaceous vegetation of threatened high altitude lateritic plateau ecosystems of Western Ghats, southwestern Maharashtra, India, Rheedea. 2012; 22(1) : 39-61.

14. Malik Vijay. Herbaceous Flora of Muzaffarnagar District (U.P.), Scholars Academic Journal of Biosciences (SAJB). 2015; 3(2B):182-196.

15. Nishitha Parappurath, Joby Paul. Herbaceous flora of sacred grooves in Perumudiyoor, Muthuthala gramapanchayath, Pattambi. South Indian Journal of Biological Sciences. 2016; 2(1) : 145151

16. Patel DK. Phyto-diversity Study with Special Reference to Herbaceous Medicinal Plants, Journal of nr uoJ Biodiversity \& Endangered Species. 2014; 2 (2) : DOI: 10.4172/2332-2543.1000123.

17. Patel D K. Herbaceous medicinal \& aromatic plants diversity and introduction in herbal garden for ex-situ conservation. International Journal of Herbal Medicine. 2014; 2 (3): 17-20.

18. Patil Rajendra, Minakshi Mahajan. Herbaceous flora of weeds growing at arai hill, pune, International journal of researches in biosciences, Agriculture and Technology (I J R B A T). 2018 ; I (VI ) : 16-19.

19. Pradhan SG, Singh NP. Flora of Ahmednagar District (Maharashtra). Published by Bishen Singh Mahendra Pal Singh, Dehradun. 1999.

20. Rathod MM. Vegetation analysis at different elevation ranges of Patanadevi forest, Maharashtra, India. Bionano Frontier. 2012; 5(2-2): 92-95.

21. Rathod MM. Vegetative species community, richness and diversity in Patnadevi forest, Maharashtra, India. Journal of environmental research and development. 2014; 8(3A): 805.

22. Santapau H. Flora of Khandala on the Western Ghats of India. Records of Botanical Survey of India. 1953.

23. Santapau H. Flora of Purandar. (Oxford Book and Stationary Company, New Delhi).1958.

24. Santapau H. Botanical collectors manual. Botanical survey of india. 1958.

25. Sharma BD, Karthikeyan S, Singh NP. Flora of Maharashtra State-Monocotyledons, (Botanical Survey of India, Calcutta, India), 1996.

26. Shikha Uniyal Gairola, Prafulla Soni. A study on herbaceous layer in an age series of restored mined land using cluster analysis; Proceedings of the International Academy of Ecology and Environmental Sciences. 2013; 3(2): 133-142.

27. Singh NP, Karthikeyan S. Flora of Maharashtra State. Volume 1 \& 2. Botanical Survey of India; Calcutta. 2001.

28. Yadav SR, Sardesai MM. Flora of Kolhapur District. Published by Shivaji University, Kolhapur-416004. 2002. 